\title{
Pancreatic Enzyme-Induced Pancreatitis and Systemic Complications in Rats
}

\author{
Mayumi Yamano, Keiji Miyata and Toshimitsu Yamada \\ Pharmacology Laboratories, Institute for Drug Discovery Research, Yamanouchi Pharmaceutical Co., Ltd., \\ 21 Miyukigaoka, Tsukuba, Ibaraki 305-8585, Japan \\ Received February 5, $1998 \quad$ Accepted April 15, 1998
}

\begin{abstract}
Effects of retrograde injection into the pancreatic duct and intravenous infusion of pancreatic enzymes and bile salt on the pancreas and other vital organs such as the liver and the lung were investigated in rats. Intraductal injection $(1 \mathrm{ml} / \mathrm{kg})$ of $\alpha$-chymotrypsin $(50-100 \mathrm{mg} / \mathrm{ml})$, trypsin $(10-100 \mathrm{mg} / \mathrm{ml})$, pancreatic elastase $(10 \mathrm{mg} / \mathrm{ml})$, lipase $(100-300 \mathrm{mg} / \mathrm{ml})$, pancreatic kallikrein $(25 \mathrm{mg} / \mathrm{ml})$ and sodium taurocholate $(50 \mathrm{mg} / \mathrm{ml})$ solutions significantly increased pancreatic water content. $\alpha$-Chymotrypsin, pancreatic elastase, taurocholate and trypsin elicited gross pancreatic hemorrhage. In contrast, lipase and kallikrein elicited gross pancreatic edema, but not hemorrhage. Intravenous infusion of trypsin $(1 \mathrm{mg} / \mathrm{kg} / \mathrm{hr})$ and pancreatic elastase $(10 \mathrm{mg} / \mathrm{kg} / \mathrm{hr})$ significantly increased pulmonary vascular permeability in rats, whereas infusion of neutrophil elastase $(0.3 \mathrm{mg} / \mathrm{kg} / \mathrm{hr})$ did not elicit these effects. Only trypsin slightly reduced arterial oxygen pressure. These results show pancreatic enzymes and bile salts induce pancreatic inflammation after retrograde injection into the pancreatic duct in rats. Furthermore, trypsin and pancreatic elastase extravasation into the vascular system can lead to pulmonary dysfunction in rats.
\end{abstract}

Keywords: Acute pancreatitis, Pancreatic enzyme, Pulmonary dysfunction, Trypsin, Elastase

Pancreatic enzymes such as chymotrypsin, trypsin, pancreatic elastase, lipase and kallikrein are secreted into the duodenal lumen to digest food. Excessive intake of alcohol or obstruction of the bile duct can induce activation of pancreatic enzymes inside the pancreatic acinar cells and regurgitation of pancreatic enzymes and bile into the pancreatic duct. These actions result in acute pancreatitis. In this state, pancreatic enzymes are liberated from inflamed pancreatic tissue. Pancreatic enzymes thus extravasated into the vascular system are thought to participate in the systemic complications seen in acute pancreatitis such as adult respiratory syndrome and multiple organ failure (1).

Many studies investigating the pathogenesis of acute pancreatitis induced by retrograde injection of taurocholate and trypsin into the pancreatic duct have been performed in rats, dogs, rabbits, pigs and sheep (2-8). Pancreatic elastase has been reported to hydrolyze elastin, a vital component of vascular tissue $(9,10)$. It may also be involved in the pathogenesis of lung injury in adult respiratory syndrome and multiple organ failure when it enters the vascular system $(1,11)$. Furthermore, elevated serum chymotrypsin, trypsin, pancreatic elastase, lipase and kallikrein levels have been observed in patients with acute pancreatitis $(12-17)$, suggesting that these pancreatic enzymes may participate in the induction and progression of acute pancreatitis. However, the pathogenicity of each pancreatic enzyme and bile salt on organs such as the pancreas, liver and lung have been rarely investigated.

In this study, the effects of retrograde injection of $\alpha$ chymotrypsin, trypsin, pancreatic elastase, lipase, pancreatic kallikrein and taurocholate into the pancreas via the common bile duct were examined in rats to investigate the participation of each pancreatic enzyme and bile salt in the development of acute pancreatitis. Their effects on hepatic and pulmonary functions via this administration route were also examined. To evaluate the effects of enzymes extravasated into the vascular system, an intravenous infusion of trypsin, pancreatic elastase and neutrophil elastase was performed, and their effects on pancreatic, hepatic and pulmonary functions in rats were examined. 


\section{MATERIALS AND METHODS}

\section{Animals}

Male Wistar rats weighing 210-290 g (SLC, Hamamatsu) were used. The animals were maintained on ordinary laboratory food and tap water ad libitum under a 12-hr light-dark cycle.

All experiments were performed in compliance with the regulations of the Animal Ethical Committee of Yamanouchi Pharmaceutical Co., Ltd.

\section{Experimental protocols}

To investigate the effects of a common bile salt and pancreatic enzymes on the pancreas, retrograde injection $(1 \mathrm{ml} / \mathrm{kg}$ ) of the bile salt and pancreatic enzyme solutions into the pancreatic duct via the common bile duct was performed in rats. Each solution was injected for $1 \mathrm{~min}$ using an infusion pump (KDS Type 220; Muromachi Kikai Co., Tokyo). $\alpha$-Chymotrypsin $(50-100 \mathrm{mg} / \mathrm{ml})$, trypsin $(10-100 \mathrm{mg} / \mathrm{ml})$, pancreatic elastase $(10 \mathrm{mg} / \mathrm{ml})$, lipase $(100-300 \mathrm{mg} / \mathrm{ml})$ and pancreatic kallikrein (25 $\mathrm{mg} / \mathrm{ml}$ ) were used as the pancreatic enzymes. Sodium taurocholate $(50 \mathrm{mg} / \mathrm{ml})$ was used as the bile salt. Pancreatic, hepatic and pulmonary functions were evaluated in rats $6 \mathrm{hr}$ after retrograde injection of the bile salt and pancreatic enzymes. Pancreatic function was assessed by pancreatic water content and serum amylase and lipase levels; hepatic function, by serum GOT and GPT levels; and pulmonary function, by arterial oxygen pressure and pulmonary vascular permeability. In preliminary experiments, the degree of pancreatitis induced by retrograde injection of the taurocholate plus trypsin solution into the common bile duct in rats was at its highest level $6 \mathrm{hr}$ after the injection.

Six hours after retrograde injection, rats were anesthetized with urethane $(1.25 \mathrm{~g} / \mathrm{kg}$, i.p. $)$, and arterial blood was taken from the left common carotid artery to measure arterial oxygen pressure. Venous blood was also taken from the inferior vena cava, and serum was then separated by centrifugation at $1500 \times g$ for $10 \mathrm{~min}$ at $4^{\circ} \mathrm{C}$. The pancreas was quickly removed, weighed, dried in an oven at $100^{\circ} \mathrm{C}$ for $24 \mathrm{hr}$, and reweighed to measure pancreatic water content.

In another series of experiments, the mortality rate was measured up to $72 \mathrm{hr}$ after retrograde injection of a bile salt and pancreatic enzymes into the pancreatic duct via the common bile duct. $\alpha$-Chymotrypsin $(50 \mathrm{mg} / \mathrm{ml})$, trypsin $(10-100 \mathrm{mg} / \mathrm{ml})$, pancreatic elastase $(10 \mathrm{mg} / \mathrm{ml})$, lipase $(100-300 \mathrm{mg} / \mathrm{ml})$ and pancreatic kallikrein (25 $\mathrm{mg} / \mathrm{ml}$ ) were used as the pancreatic enzymes. Sodium taurocholate $(50 \mathrm{mg} / \mathrm{ml})$ was used as the bile salt. The survival rate of animals given an intraductal injection of $\alpha$-chymotrypsin $(100 \mathrm{mg} / \mathrm{ml})$ was measured for only $6 \mathrm{hr}$.
The effects of trypsin, and pancreatic and neutrophil elastases after intravenous infusion on pancreatic, hepatic and pulmonary functions were then evaluated using the following indicators: Pancreatic function was assessed by pancreatic water content and serum amylase and lipase levels; hepatic function, by serum GOT and GPT levels; and pulmonary function, by arterial oxygen pressure and pulmonary vascular permeability. Rats were anesthetized with urethane $(1.25 \mathrm{~g} / \mathrm{kg}$, i.p.), and trypsin $(1 \mathrm{mg} / \mathrm{kg} / \mathrm{hr})$, pancreatic elastase $(10 \mathrm{mg} / \mathrm{kg} / \mathrm{hr})$ and neutrophil elastase $(0.3 \mathrm{mg} / \mathrm{kg} / \mathrm{hr})$ were intravenously infused for $6 \mathrm{hr}$ by an infusion pump at a rate of $0.6 \mathrm{ml} / \mathrm{hr}$ via the left femoral vein. Seven hours after the start of infusion, blood was taken, and the pancreas was removed, weighed, dried in oven at $100^{\circ} \mathrm{C}$ for $24 \mathrm{hr}$, and reweighed to measure pancreatic water content.

\section{Measurement of pulmonary vascular permeability}

To examine pulmonary vascular permeability, anesthetized rats were injected with $0.5 \%$ Evans blue $(1 \mathrm{ml} / \mathrm{rat}$, i.v.) $30 \mathrm{~min}$ before removal of the lungs. The lungs were perfused through the right cardiac ventricle with physiological saline to eliminate blood from the lungs and then quickly removed. The lungs were minced and soaked in formamide $(3 \mathrm{ml})$ for 2 days at $4{ }^{\circ} \mathrm{C}$. The minced lungs were centrifuged at $1500 \times \mathrm{g}$ for $10 \mathrm{~min}$ at $4^{\circ} \mathrm{C}$, and the supernatant was collected. Absorbance at $620 \mathrm{~nm}$ was measured with a spectrophotometer (V-520; Nihon Kohden, Tokyo). Results are expressed as $\mu \mathrm{g}$ of Evans blue per $\mathrm{ml}$.

\section{Biochemical determinations}

Serum amylase, lipase, GOT and GPT were measured with an automatic analyzer (type 7250; Hitachi, Tokyo). Aliquots $(500 \mu 1)$ of $1: 1$ to $1: 50$ dilutions of the serum were used in the assay. Arterial oxygen pressure was measured with a Ciba Corning 280 Blood Gas System (Ciba-Corning, Tokyo).

\section{Statistics}

All values are expressed as the mean \pm S.E.M. The differences between treatment groups were compared by Dunnett's multiple range test and Student's $t$-test. Probabilities of $<5 \%(\mathrm{P}<0.05)$ were considered significant.

\section{Drugs}

Bovine $\alpha$-chymotrypsin (47 U/mg), porcine trypsin $(1870 \mathrm{U} / \mathrm{mg})$, porcine pancreatic elastase $(100 \mathrm{U} / \mathrm{mg})$, porcine lipase $(11.9 \mathrm{U} / \mathrm{mg})$, porcine pancreatic kallikrein $(40 \mathrm{U} / \mathrm{mg})$ and sodium taurocholate were purchased from Sigma Chemical Co. (St. Louis, MO, USA). Human neutrophil elastase $(800 \mathrm{U} / \mathrm{mg})$ was purchased from Elastin 
Products Company, Inc. (Owensville, MO, USA). All drugs were dissolved in physiological saline.

\section{RESULTS}

Effects of pancreatic enzymes and bile salt on the pancreas

Retrograde injection of $\alpha$-chymotrypsin (50-100 $\mathrm{mg} / \mathrm{ml})$, trypsin $(10-100 \mathrm{mg} / \mathrm{ml})$, pancreatic elastase (10 $\mathrm{mg} / \mathrm{ml})$, lipase $(100-300 \mathrm{mg} / \mathrm{ml})$, pancreatic kallikrein $(25 \mathrm{mg} / \mathrm{ml})$ and sodium taurocholate $(50 \mathrm{mg} / \mathrm{ml})$ solutions into the pancreatic duct induced significant increase in the pancreatic water content in rats (Fig. 1A). $\alpha$ Chymotrypsin, pancreatic elastase, taurocholate and higher concentrations of trypsin $(50-100 \mathrm{mg} / \mathrm{ml})$ elicited gross pancreatic hemorrhage. On the other hand, lipase, kallikrein and a low concentration of trypsin $(10 \mathrm{mg} / \mathrm{ml})$ elicited gross pancreatic edema, but did not elicit pancreatic hemorrhage. By superficial observation, ascitic volume increased after administration of $\alpha$-chymotrypsin, trypsin, pancreatic elastase, kallikrein and taurocholate, but not lipase. Bile salt and all pancreatic enzymes except kallikrein also elevated serum amylase and lipase levels (Fig. 1: B and C). The higher concentration of kallikrein $(50 \mathrm{mg} / \mathrm{ml})$ had no significant effect on the pancreatic water content, serum amylase or lipase levels after retrograde injection into the pancreatic ducts (data not shown, $\mathrm{n}=7$ ).

The highest concentration of $\alpha$-chymotrypsin (100 $\mathrm{mg} / \mathrm{ml}$ ) significantly increased serum GOT and GPT levels and arterial oxygen pressure (Fig. 2). Serum GOT level was also significantly increased by pancreatic elastase and taurocholate (Fig. 2A). The other pancreatic enzymes had no significant effect on hepatic or pulmonary functions (Fig. 2). Intraductal injection of $\alpha$-chymotrypsin, trypsin, pancreatic elastase, lipase, kallikrein and taurocholate had no effect on pulmonary vascular permeability (data not shown, $n=6-9$ ).

In another series of experiments, the effects of retrograde injection of pancreatic enzymes and bile salt into the pancreatic ducts on the mortality rate were evaluated. Trypsin, pancreatic elastase and kallikrein did not cause death in rats for at least $72 \mathrm{hr}$ after the injection (data not shown, $n=10$ ). However, administration of taurocholate resulted in the highest death rate. Mortality in taurocholate-treated rats reached $70 \% 72 \mathrm{hr}$ after injection (data not shown, $\mathrm{n}=10$ ). The mortality caused by treatment with the low concentration of $\alpha$-chymotrypsin was $22.2 \% 72 \mathrm{hr}$ after injection (data not shown, $\mathrm{n}=9$ ), but that caused by the high concentration $\alpha$-chymotrypsin was 30\% $6 \mathrm{hr}$ after injection (data not shown, $\mathrm{n}=10$ ). The mortality caused by lipase $(300 \mathrm{mg} / \mathrm{ml})$ treatment was $33.3 \% 72 \mathrm{hr}$ after injection (data not shown, $\mathrm{n}=9$ ).
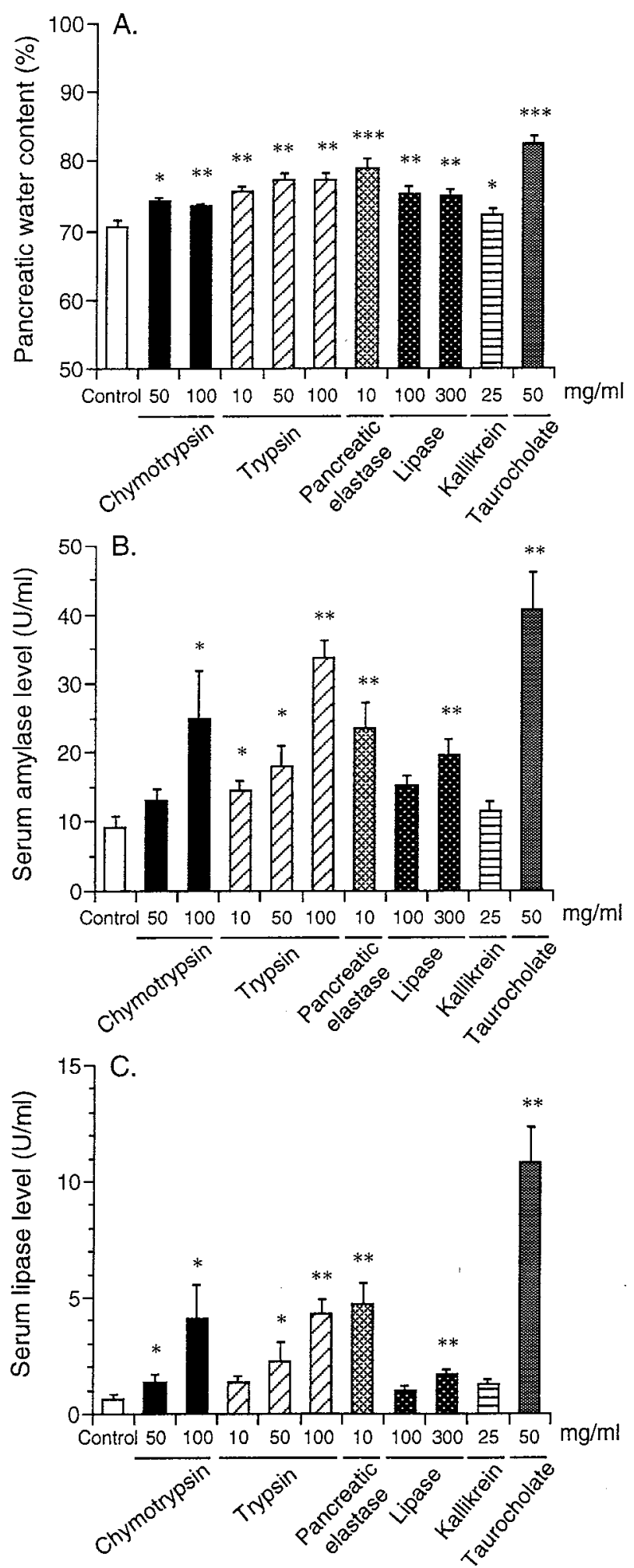

Fig. 1. Effects of $\alpha$-chymotrypsin, trypsin, pancreatic elastase, lipase, kallikrein and taurocholate on pancreatic water content (A), serum amylase (B) and serum lipase (C) levels $6 \mathrm{hr}$ after retrograde injection $(1 \mathrm{ml} / \mathrm{kg})$ into the pancreatic duct in rats. Data are expressed as the mean \pm S.E.M. of 6 to 9 animals. ${ }^{*} \mathrm{P}<0.05$, ${ }^{* *} \mathrm{P}<0.01,{ }^{* * *} \mathrm{P}<0.001$, compared to the control group (Dunnett's multiple range test). 

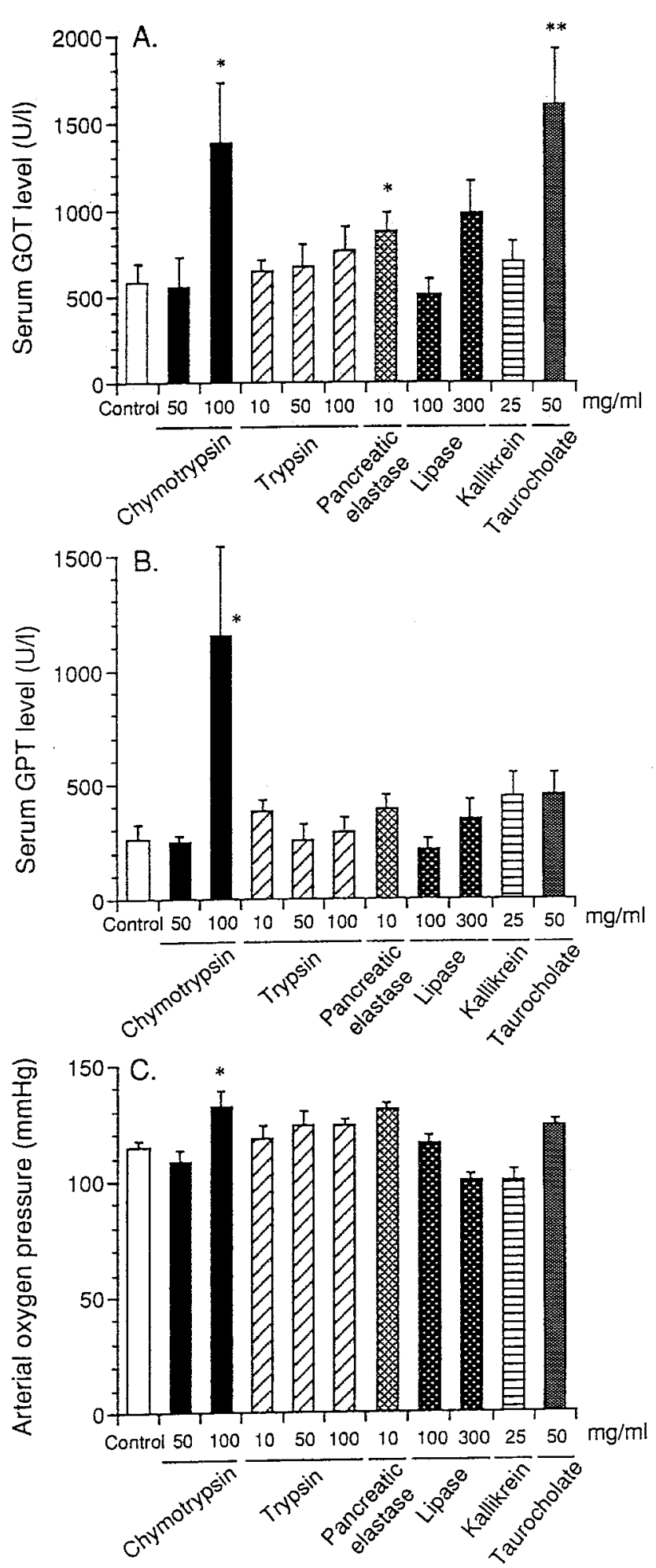

Fig. 2. Effects of $\alpha$-chymotrypsin, trypsin, pancreatic elastase, lipase, kallikrein and taurocholate on serum GOT (A) and GPT (B) levels and arterial oxygen pressure (C) $6 \mathrm{hr}$ after retrograde injection $(1 \mathrm{ml} / \mathrm{kg})$ into the pancreatic duct in rats. Data are expressed as the mean \pm S.E.M. of 6 to 9 animals. ${ }^{*} \mathrm{P}<0.05,{ }^{* *} \mathrm{P}<0.01$, compared to the control group (Dunnett's multiple range test).
Effects of intravenous infusion of trypsin, pancreatic elastase and neutrophil elastase

Intravenous infusion of trypsin $(1 \mathrm{mg} / \mathrm{kg} / \mathrm{hr})$ and pancreatic elastase $(10 \mathrm{mg} / \mathrm{kg} / \mathrm{hr})$ for $6 \mathrm{hr}$ significantly increased pulmonary vascular permeability in rats, whereas infusion of neutrophil elastase $(0.3 \mathrm{mg} / \mathrm{kg} / \mathrm{hr})$ did not significantly increase permeability (Fig. 3: A-C). Arterial oxygen pressure was only slightly reduced by trypsin, but was not reduced by either pancreatic or neutrophil elastase (Fig. 3: D-F). Pancreatic water content, and serum amylase, lipase, GOT and GPT levels were not changed by trypsin, pancreatic elastase or neutrophil elastase after intravenous infusion for $6 \mathrm{hr}$ (data not shown, $\mathrm{n}=8-10$ ).

\section{DISCUSSION}

Many pancreatic enzymes and bile salts are by nature pathogenic because they have the potency to digest proteins and lipids. Therefore, when these substances are regurgitated into the pancreas or extravasated into the vascular system, acute pancreatitis and the destruction of vital organs including hepatic, renal and pulmonary failures commonly occur. In the present study, the effects of retrograde injection of a common bile salt and pancreatic enzymes into the pancreatic duct on pancreatic, hepatic and pulmonary functions were examined in rats to investigate the participation of bile salt and each pancreatic enzyme in the development of acute pancreatitis. To evaluate the participation of enzymes extravasated into the systemic circulation in pancreatitis-induced organ failures, the effects of intravenous infusions of trypsin, pancreatic elastase and neutrophil elastase on pancreatic, hepatic and pulmonary functions were also examined.

Intraductal injection of $\alpha$-chymotrypsin, trypsin, pancreatic elastase, lipase, pancreatic kallikrein and sodium taurocholate solutions induced significant increases in pancreatic water content in rats. $\alpha$-Chymotrypsin, pancreatic elastase, taurocholate and the higher concentrations of trypsin elicited gross pancreatic hemorrhage. Lipase, kallikrein and the low concentration of trypsin elicited gross pancreatic edema. $\alpha$-Chymotrypsin significantly increased serum GOT and GPT levels and arterial oxygen pressure. This increase in arterial oxygen pressure is thought to be responsible for the respiratory compensation for the arterial acidosis. In this study, arterial $\mathrm{pH}$ significantly decreased in rats with intraductal injection of $\alpha$-chymotrypsin ( $\alpha$-chymotrypsin: 7.36 vs control: 7.49 ). The peripheral chemoreceptors play a dominant role in the respiratory compensation of arterial acidosis. $\alpha$ Chymotrypsin-induced arterial acidosis might evoke hyperpnea, leading to the increase in arterial oxygen pressure. Serum GOT level increased significantly due to 

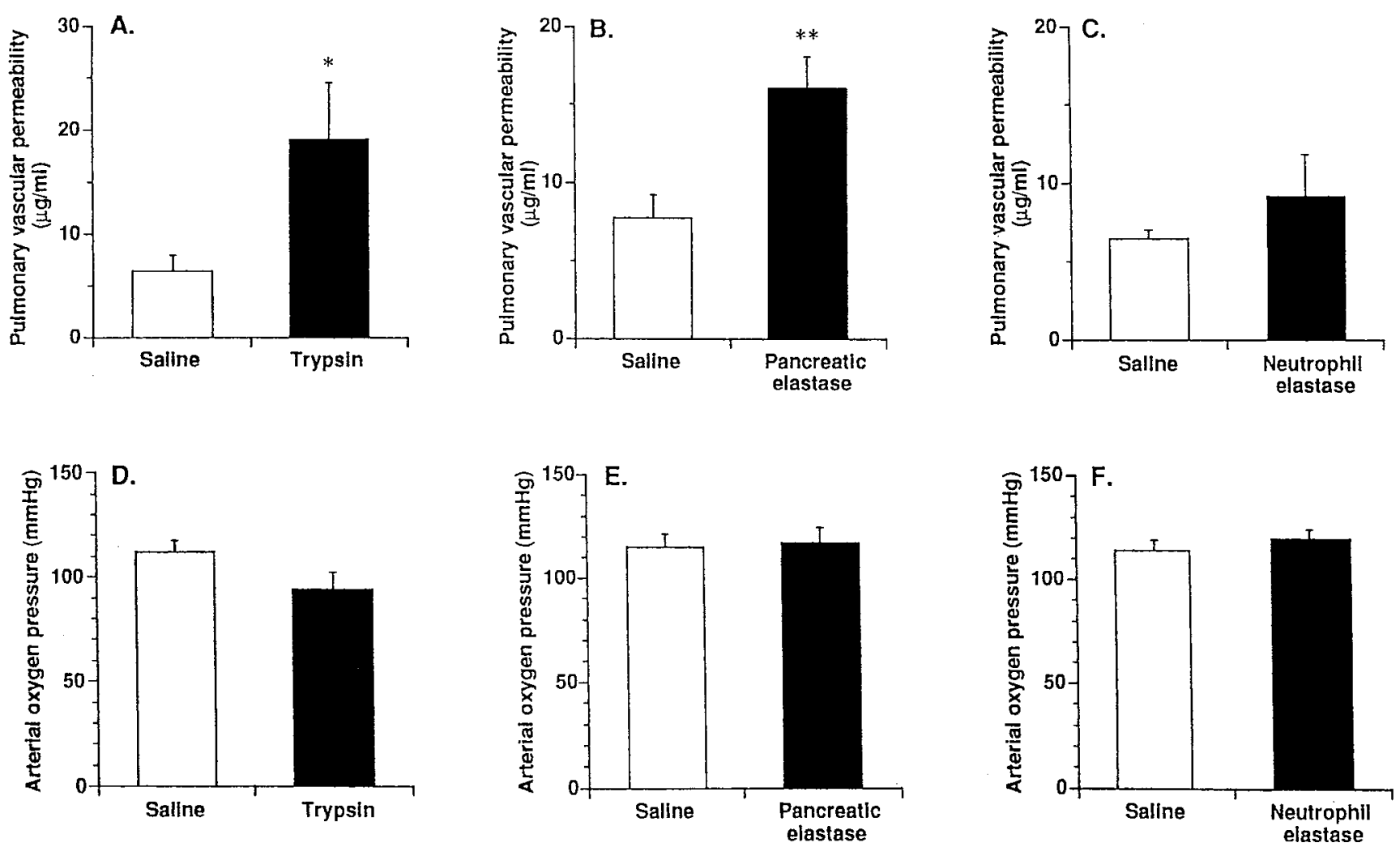

Fig. 3. Effects of trypsin $(1 \mathrm{mg} / \mathrm{kg} / \mathrm{hr})$, pancreatic elastase $(10 \mathrm{mg} / \mathrm{kg} / \mathrm{hr})$ and neutrophil elastase $(0.3 \mathrm{mg} / \mathrm{kg} / \mathrm{hr})$ on pulmonary vascular permeability $(\mathrm{A}-\mathrm{C})$ and arterial oxygen pressure $(\mathrm{D}-\mathrm{F}) 7 \mathrm{hr}$ after the start of infusion in rats. All enzymes were intravenously infused for $6 \mathrm{hr}$. Data are expressed as the mean \pm S.E.M. of 8 to 10 animals. ${ }^{*} P<0.05,{ }^{* *} P<0.01$, compared to the saline-treated group (Dunnett's multiple range test).

administration of pancreatic elastase and taurocholate. $\alpha$-Chymotrypsin and taurocholate very significantly increased the death rate, while lipase only slightly increased mortality. These results show that the bile salt and all pancreatic enzymes used in this study induce pancreatic inflammation after retrograde injection into the pancreatic ducts in rats. Death induced by $\alpha$-chymotrypsin might be due to hepatic dysfunction accompanying pancreatic inflammation. On the other hand, taurocholate-induced death was not due to hepatic and pulmonary dysfunction. In the preliminary experiment, serum blood urea nitrogen was significantly elevated in rats with intraductal injection of taurocholate (data not shown, $n=9$ ), indicating that renal dysfunction might be involved in death induced by taurocholate. In contrast, the results also indicate that pancreatic kallikrein probably plays a minor role in the pathogenesis of pancreatitis because it only causes slight pancreatic edema after intraductal injection in rats.

In isolated rat pancreatic acinar cells, pancreatic elastase had the greatest deleterious effect among lipase, $\alpha$-chymotrypsin, pancreatic elastase, phospholipase $\mathrm{A}_{2}$ $\left(\mathrm{PLA}_{2}\right)$ and trypsin (18). It was also suggested that trypsin itself was markedly less noxious to acinar cells when compared with the other pancreatic enzymes, indicating that activation of trypsin might be the trigger to start the activation cascade in acute pancreatitis. Hong et al. (19) reported that cat pancreas perfused intra-arterially with bile acids caused massive parenchymal pancreatic necrosis, and trypsin infusion caused focal necrosis. In contrast, pancreatic elastase or PLA $\mathrm{A}_{2}$ had little influence on pancreatic function or structure. In this study, the extent of pancreatic inflammation induced by intraductal injection of the bile salt and several pancreatic enzymes was not remarkably different. Therefore, evidence suggests that $\alpha$-chymotrypsin, trypsin, pancreatic elastase, lipase and taurocholate directly or indirectly attack pancreatic tissue, resulting in autodigestion of the pancreas.

The elevation of plasma neutrophil elastase level was observed in patients with severe acute pancreatitis $(20$, 21). Serum trypsin and pancreatic elastase (pancreatic enzymes) levels were also elevated in patients with acute pancreatitis $(13,15,17,20,22,23)$. Results from a similar rat study also indicate that pancreatic elastase extravasated into the vascular system plays a major role in the development of pulmonary vascular injury accompanying induced acute pancreatitis (11). Tahamont et al. (2) 
reported that pulmonary damage induced by intravenous infusion of trypsin was comparable to that observed after intraductal injection of bile in sheep, suggesting that the release of pancreatic proteases into the systemic circulation after acute pancreatitis might be an initiating event mediating pulmonary injury.

In this study, intravenous infusion of trypsin and pancreatic elastase for $6 \mathrm{hr}$ significantly increased pulmonary vascular permeability in rats, whereas infusion of neutrophil elastase did not remarkably increase permeability. However, arterial oxygen pressure was only slightly decreased by trypsin, but not by either pancreatic or neutrophil elastase in rats. These results suggest that intravenous infusion of trypsin and pancreatic elastase induces pulmonary dysfunction in rats. This lung injury may be comparable to that accompanying acute pancreatitis. Reichart et al. (24) reported that intravenous infusion of trypsin for $1 \mathrm{hr}$ induced early lung leucostasis and delayed onset emphysema (6 or 12 weeks after the trypsin infusion) in rats and hamsters. In sheep, intravenous infusion of trypsin also induced a neutrophil-dependent increase in lung vascular permeability (25). Intravenous infusion of pancreatic elastase $(330 \mathrm{U} / \mathrm{kg} / \mathrm{hr})$ also elicited pulmonary leucostasis, interstitial edema and progressive respiratory failure in pigs, whereas bolus intravenous injection of pancreatic elastase $(1330 \mathrm{U} / \mathrm{kg})$ into hamsters had no significant effect on lung elastin $(26,27)$. The results described in this report are largely consistent with these previous findings. In this report, the acute effects of intravenous trypsin, pancreatic elastase and neutrophil elastase administration on pulmonary function were evaluated, but the chronic effects of these proteases might be more remarkable. Although neutrophil elastase had no marked effect on pulmonary function in this study, further studies using higher doses of protease are needed to confirm the effect of neutrophil elastase.

In conclusion, the bile salt and all pancreatic enzymes used in the present study induce pancreatic inflammation after retrograde injection into the pancreatic ducts of rats. Among these enzymes, $\alpha$-chymotrypsin might also induce hepatic dysfunction which accompanies pancreatic inflammation. The results also suggest that trypsin and pancreatic elastase extravasated into the vascular system lead to pulmonary dysfunction in rats.

\section{REFERENCES}

1 Montravers P, Chollet-Martin S, Marmuse JP, GougerotPocidalo MA and Desmonts JM: Lymphatic release of cytokines during acute lung injury complicating severe pancreatitis. Am J Respir Crit Care Med 152, 1527-1533 (1995)

2 Tahamont MV, Barie PS, Blumenstock FA, Hussain MH and Malik AB: Increased lung vascular permeability after pancreatitis and trypsin infusion. Am J Pathol 109, 15-26 (1982)
3 Puolakkainen $\mathrm{P}$, Paananen A, Kaarne M, Kuusi T, Lempinen $\mathrm{M}$ and Schroder $\mathrm{T}$ : Aprotinin and $\mathrm{Na}_{2} \mathrm{CaEDTA}$ in experimental hemorrhagic pancreatitis in pigs. Scand $\mathrm{J}$ Gastroenterol 22, 35-41 (1987)

4 Kiviniemi H, Stahlberg MI, Jalovaara P, Ramo J and Kairaluoma M: Methylprednisolone in acute canine hemorrhagic pancreatitis. Acta Chir Scand 154, 31-35 (1988)

5 Chardavoyne R, Asher A, Bank S, Stein TA and Wise L: Role of reactive oxygen metabolites in early cardiopulmonary changes of acute hemorrhagic pancreatitis. Dig Dis Sci 34, $1581-1584$ (1989)

6 Zhu ZH, Holt S, el Lbishi MS, Grady T, Taylor TV and Powers RE: A somatostatin analogue is protective against retrograde bile salt-induced pancreatitis in the rat. Pancreas 6, 609-613 (1991)

7 Klar E, Schratt W, Foitzik T, Buhr H, Herfarth C and Messmer $\mathrm{K}$ : Impact of microcirculatory flow pattern changes on the development of acute edematous and necrotizing pancreatitis in rabbit pancreas. Dig Dis Sci 39, 2639-2644 (1994)

8 Nakae Y, Naruse S, Kitagawa M, Hirao S, Yamamoto R and Hayakawa $\mathrm{T}$ : Activation of trypsinogen in experimental models of acute pancreatitis in rats. Pancreas 10, 306-313 (1995)

9 Stone PJ, Morris SM, Martin BM, McMahon MP, Faris B and Franzblau C: Repair of protease-damaged elastin in neonatal rat aortic smooth muscle cell cultures. J Clin Invest 82, 1644- 1654 (1988)

10 Morris SM and Stone PJ: Immunocytochemical study of the degradation of elastic fibers in a living extracellular matrix. J Histochem Cytochem 43, 1145-1153 (1995)

11 Lungarella G, Gardi C, de Santi MM and Luzi P: Pulmonary vascular injury in pancreatitis: evidence for a major role played by pancreatic elastase. Exp Mol Pathol 42, 44-59 (1985)

12 Toki N, Sumi $\mathrm{H}$ and Takasugi S: Purification and characterization of kallikrein from plasma of patients with acute pancreatitis. Clin Sci 60, 199-205 (1981)

13 Fujimoto K, Ogawa M, Murata A, Kitahara T, Takatsuka $Y$ and Kosaki G: Diagnostic significance of immunological assay of pancreatic elastases in acute pancreatitis. Clin Biochem 16, $26-27$ (1983)

14 Iwaki K, Ogawa M, Tanaka S and Kosaki G: Radioimmunoassay for human pancreatic chymotrypsin and measurement of serum immunoreactive chymotrypsin contents in various diseases. Res Commun Chem Pathol Pharmacol 40, 489-496 (1983)

15 Lesi C, Ruffilli E, De-Mutiis R, Zoni L, Baldoni F and Malaguti P: Serum elastase 1 in clinical practice. Pancreas 3, 444-449 (1988)

16 Vaziri ND, Chang D, Malekpour A and Radaht S: Pancreatic enzymes in patients with end-stage renal disease maintained on hemodialysis. Am J Gastroenterol 83, 410-412 (1988)

17 Le Moine O, Devaster JM, Deviere J, Thiry P, Cremer M and Ooms HA: Trypsin activity. A new marker of acute alcoholic pancreatitis. Dig Dis Sci 39, 2634-2638 (1994)

18 Niederau C, Fronhoffs K, Klonowski $\mathrm{H}$ and Schulz HU: Active pancreatic digestive enzymes show striking differences in their potential to damage isolated rat pancreatic acinar cells. J Lab Clin Med 125, 265-275 (1995)

19 Hong SS, Case RM and Kim KH: Analysis in the isolated perfused cat pancreas of factors implicated in the pathogenesis of pancreatitis. Pancreas 3, 450-458 (1988) 
20 Balldin G, Borgstrom A, Genell S and Ohlsson K: The effect of peritoneal lavage and aprotinin in the treatment of severe acute pancreatitis. Res Exp Med Berl 183, 203-213 (1983)

21 Bergenfeldt M, Berling R and Ohlsson K: Levels of leukocyte proteases in plasma and peritoneal exudate in severe, acute pancreatitis. Scand J Gastroenterol 29, 371-375 (1994)

22 Ventrucci M, Pezzilli R, Gullo L, Plate L, Sprovieri G and Barbara L: Role of serum pancreatic enzyme assays in diagnosis of pancreatic disease. Dig Dis Sci 34, 39-45 (1989)

23 Malfertheiner P and Kemmer TP: Clinical picture and diagnosis of acute pancreatitis. Hepatogastroenterology 38, 97-100 (1991)

24 Reichart E, Boerkmann P, Plenat F, Marie B, Rogerieux F and
Lambre C: The trypsin-induced leucostasis which leads to emphysema in the hamster is not due to contaminating endotoxins. J Pathol 178, 215-220 (1996)

25 Garcia-Szabo RR, Johnson A and Malik AB: Leukocytes are required for the trypsin-induced increase in lung vascular permeability. Am J Pathol 124, 377-383 (1986)

26 Ip MP, Kleinerman J and Sorensen J: The effect of elastase on pulmonary elastin and collagen: comparison of intravenous and intratracheal exposure. Exp Lung Res 1, 181-189 (1980)

27 Stokke T, Burchardi H, Hensel I, Kostering H, Kathner T and Rahlf G: Continuous intravenous infusion of elastase in normal and agranulocytic minipigs - effects on the lungs and the blood coagulation system. Resuscitation 14, 61-79 (1986) 